園学雑. (J. Japan. Soc. Hort. Sci.) 55(4) : 434-444. 1987.

\title{
“宮内イヨカン’の着花が開花期の窒素と 光合成産物の転流飞及汸寺影響1
}

\author{
高木信雄・清水真寿美 ${ }^{2} \cdot$ 荻野尚裕 $^{3}$ \\ 前田幸男・赤松 聡・大和田厚 \\ 愛媛県果樹試験場 761-01 松山市下伊台町
}

\author{
Influence of Flowering Intensity on the Vegetative Growth and \\ Translocation of ${ }^{15} \mathrm{~N}$ and ${ }^{13} \mathrm{C}$-Photosynthates during \\ Anthesis in Miyauchi iyo (Citrus iyo hort. Tanaka) \\ Nobuo Takagi, Masumi Shimizu, Naohiro Ogino, \\ Yukio Maeda, Satoshi Akamatsu and Atsushi Owada \\ Ehime Prefectural Fruit Tree Experiment Station, \\ Shimoidai, Matsuyama 791-01
}

\section{Summary}

In this experiment ${ }^{15} \mathrm{~N}$ and ${ }^{13} \mathrm{C}$ were used as tracer elements. With an increase of flowering load, percentage fruit setting and the number of shoots of spring flush decreased. The percentage fruit setting was particularly lowered by an increase of leafless inflorescences.

In trees where the ratio of leaf to flower number was less than 10 , the total amount of nitrogen contained in the dropped flowers was more than $10 \%$ of the nitrogen in all the fruit harvested in autumn.

The percentage fruit setting of leafy inflorescences was higher and the ovary growth during 4 to 5 days of preflowering stage was greater than that of leafless inflorescences. It was also confirmed that the nitrogen which had been applied on April 20, was absorbed and translocated to new shoots as well as to flowers at anthesis. Thus it seems that the nitrogen promoted photosynthesis and increased the fruit setting. On the other hand, nitrogen which had been applied on May 8, had almost no effect on fruit setting but contributed to the development new shoots after anthesis. Most of the nitrogen which was applied on September 1, was steadily absorbed until mid November. ${ }^{15} \mathrm{~N}$ content in the leaves remained almost constant until the following February. Throughout the period from March to May, ${ }^{15} \mathrm{~N}$ content of shoots, leaves and fibrous root decreased, while that of the new leaves and flower organs increased. ${ }^{15} \mathrm{~N}$ which was applied on April 20 as well as on September 1 was uniformly distributed to plant parts such as flower organs and new shoots. Dropped flower organs contained a considerable amount of the ${ }^{15} \mathrm{~N}$. This shows that much of the nitrogen in the flower organs was lost through flower dropping.

Although a lot of ${ }^{13} \mathrm{C}$-photosynthates was translocated to leafy inflorescences, the total amount of ${ }^{13} \mathrm{C}$ in the dropped flowers was greater. Among the plant parts, ${ }^{13} \mathrm{C}$ content was highest in the new leaves through anthesis. ${ }^{13} \mathrm{C}$ content in the old leaves decreased rapidly while that of flower organs increased.

1 1986年 2 月 12 日 受理

2 現在 温泉青果農業協同組合

3 多木化学株式会社

本報告の要旨は園芸学会昭和58年度及び60年度秋季大会で発表した。本研究の一部は農林水産省総合助成試験費 補助金によって行われた。 


\section{緒言}

宮内イヨカンは，昭和50年ころよりウンシュウミカン の生産過剩に対する高接ぎ更新の主力品種として，全国 的に栽培面積が急増した. しかし，結実期に達した後の 更新樹の樹冠の拡大は遅く，その生産性はウンシュウミ カンに比べて著しく低い(17).

豊産性の本種の生育は，着花や結実は良好であるが， 枝梢の生長が不良で樹勢が弱い，着花結実と枝梢の生長 の相互関係については多くの報告 $(20,22,24)$ があるが, 従来の研究は, ウンシュウミカンの着花結実性の向上に 関するものが多い。また，花や新梢の形成に対して，貯 蔵炭水化物や窒素の重要性が明らかにされているが(1,

2), 宮内イヨカンのように生殖生長が栄養生長を制限す る場合の着花の栄養生理的意義は不明な部分が多い.

一方，カンキツの枝葉による窒素吸収は初夏から夏期 に多く(6)，また，生育に対しても春肥や夏肥施用の窒 素は，秋肥施用のそれよりも効果が高い $(14,25)$. しか し，カンキッの開花期ころに施用される “花肥” は落花 を助長するとされており，従来はほとんど施用されてい なかった。

そこで，宮内イヨカンの着花過多が生育に及ぼす影 響, 並びに開花期の ${ }^{15} \mathrm{~N}$ 標識窒素と ${ }^{13} \mathrm{C}$ 標識光合成産物 の花や新梢への転流の様相を明らかにすることによっ て, 本種の着花過多に対する施肥窒素の意義を検討し た.

\section{材料及び方法}

\section{1. 生育特性と花による窒素の消費}

愛媛県果樹試験場東野围場において， $1.8 \mathrm{~m} \times 1.8 \mathrm{~m}$ に栽植された 9 年生カラタチ台宮内イヨカン 20 樹を供試 した，1982年 5 月 12 日に花数，同年 8 月 7 日に結果数， 新梢及び葉数を調査し，葉果比80を基準に摘果した．各 時期に 1 樹から花を 50 個，摘果果実を 10 個採取し窒素含 量を分析した．窒素含量と乾物重からそれらに含まれる 窒素量を樹別に求めた.

\section{2. 花肥と初秋施用 ${ }^{15} \mathrm{~N}$ の花及び新梢への} 転流

$30 \mathrm{~cm} \times 45 \mathrm{~cm} \times$ 深さ $30 \mathrm{~cm}$ のポットに栽植されたカ ラタチ台 5 年生樹を各区 3 樹ずつ供試した。花肥は1982 年 4 月 20 日と 5 月 8 日に $7.07^{15} \mathrm{Natom} \%$ excess 硫安を $20 \mathrm{~g}$ ずつ施用し, 施用後 $30 \mathrm{~mm}$ のかん水を行った. た， $10.2{ }^{15}$ Natom $\%$ excess 尿素の $0.5 \%$ 液を 5 月 8 日 に葉面散布した。 その際, 散布液の花への付着を防止す るため, 散布直前に 1 樹当たり 30 個の有葉花とその新梢 をビニル袋で覆い，袋かけ区とした．なお，開花初めは 5 月 8 日で, 花は 5 月 12 日に，新葉と幼果は 6 月 15 日に
採取した。また，供試樹にはその年の春肥は施用しなか った.

次に, 前述の 9 年生樹を 2 樹供試し, 1982年 9 月 1 日 に, $7.08{ }^{15} \mathrm{Natom} \%$ excess 硫安を窒素で $100 \mathrm{~g}$ ずつを $10 l$ の水に溶解し均一に施用した. 施用後, 1 樹は草生 栽培し， 1 樹は除草剤で裸地化した。その後同年11月中 旬と翌年 3 月上旬に窒素で $50 \mathrm{~g}$ ずつを ${ }^{14} \mathrm{~N}$ 硫安で施用 した．第 7 図に示す時期に，花，新梢，葉，果実と土壤 及び細根を適宜採取し，窒素と ${ }^{15} \mathrm{~N}$ の分析に供した.土 壌は検土杖で採取し，細根は樹冠下から採取した。

${ }^{15} \mathrm{~N}$ は発光法によって, 加藤らの方法(10)で測 定し た.

\section{3. 開花期の ${ }^{13} \mathrm{C}$ 標識光合成産物の転流}

愛媛県果樹試験場伊台圑場に栽植されたカラタチ台 4 年生樹を供試し, 開花初めの1985年 5 月 9 日（晴天） に，第 1 図のと拈り ${ }^{13} \mathrm{CO}_{2}$ を同化させた。. ${ }^{13} \mathrm{CO}_{2}$ は 91 atom $\% \mathrm{Ba}^{13} \mathrm{CO}_{3} 7.5 \mathrm{~g}$ ずつを $50 \%$ 乳酸で, 午前 7 時と 9 時に発生させて午後 1 時まで同化させた. 処理直後と 翌朝 7 時に花蕾と新梢を, また処理 5 日後に樹体を解体 し試料を採取した。試料は採取後直ちに $100^{\circ} \mathrm{C}$ で乾燥 し, 重量測定後振動ミルで微粉末とした。 ${ }^{13} \mathrm{C}$ は農林水 産省四国農業試験場において, 日本分光社製 ${ }^{13} \mathrm{CO}_{2}$ アナ ライザーで測定した $(15,27)$.

施用 ${ }^{15} \mathrm{~N}$ と ${ }^{13} \mathrm{C}$ の転流は久保田ら(13)の方法に準じ て, 各部位の施用 $\mathrm{N}$ と の占める割合 $={ }^{15} \mathrm{~N}$ あいい ${ }^{13} \mathrm{C}$ 寄与率（各部位の atom $\%$ excess/施用 atom $\%$ excess）と移行量=寄与率 $\times$ 各部位の乾物重で比較した。 なお， atom\% excess は, atom\%から自然界に存在する 濃度，すなわち ${ }^{15} \mathrm{~N}$ は $0.365 \%,{ }^{13} \mathrm{C}$ は $1 \%$ を減じた数

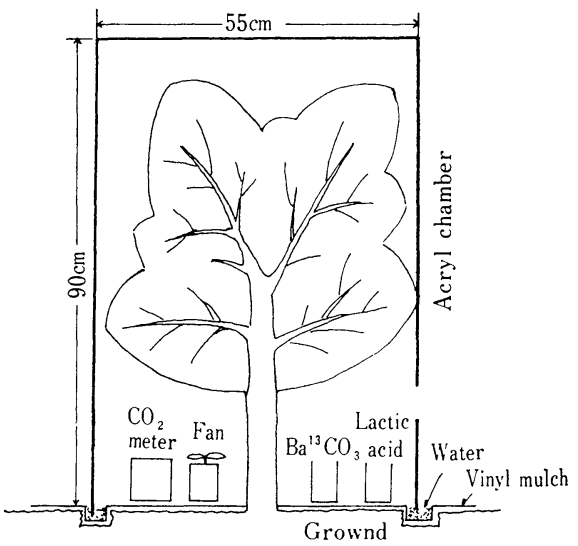

Fig. 1. Methods for ${ }^{13} \mathrm{CO}_{2}$ feeding to a Miyauchi iyo tree under orchard conditions. 
值である.

\section{結果}

\section{1. 生育特性と花による窒素の消費}

調查樹の中で，着花過多樹之着花少樹の 3 樹ずつにつ いて，新梢の発生数と結実率を第 $2 ， 3$ 図に対比した. 着花過多樹では, 直花が着花少樹の 15 倍以上も着花し たが，両樹とも直花はほとんど結実しなかった．着花 過多樹の新梢数は著しく少なかったが，両樹とも着果枝 と無着果枝の中で, 後者の割合が $90 \%$ 以上で著しく多 かった. しかも，無着果枝の中で, $5 \mathrm{~cm}$ 未満の弱小枝の 比率が高く，特に着花過多樹では約 $85 \%$ を占めた。次 に，母枝の先端から各節位ごとに，新梢と着果枝の発生 数とその長さを第 4 図に示した．母枝当たりの平均新梢 発生数は，着花過多樹で約 2 本，着花少樹で約 1.4 本で あった．両樹とも第 1 節位からの新梢の発生が多く，ま た，有葉果の着生もこの節位で多かった。しかし，2節 目以下からも全体の $60 \%$ 以上の新梢と着果枝が発生し た、なお，新梢の長さは発生する節位によってほとんど 差がなかった。

全調査樹について，着花数と新梢発生数及び 葉花比 （着葉数／着花数）と結実率の関係を第 5,6 図に示し

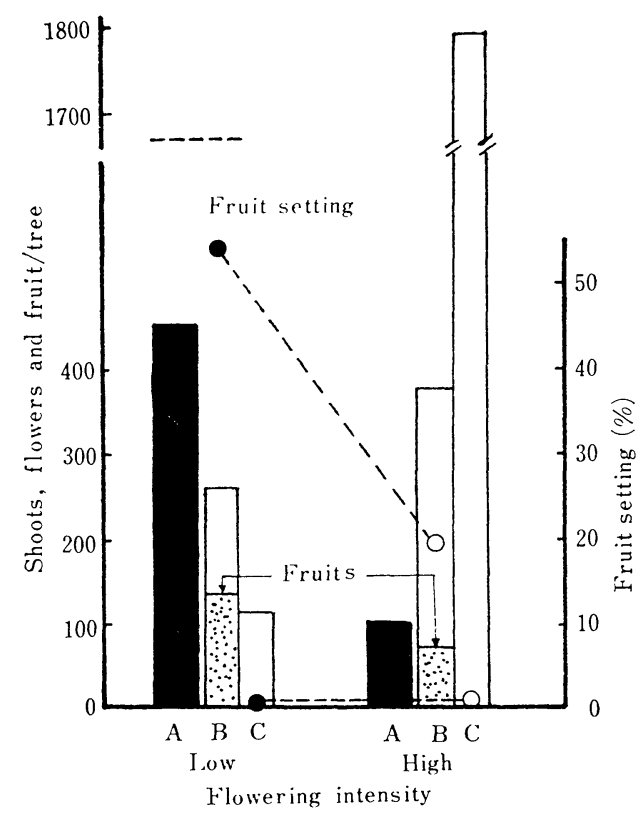

Fig. 2. The influence of the inflorcscences on flower types, fruit-setting and spring flushes in 8-yearold Miyauchi iyo trees. (A : Shoots, B : Leafy inflorescences, $\mathrm{C}:$ Leafless inflorescences)
た. 着花数と新梢発生数の間には, 有意な負の相関関係 が認められ，花が 5 個増えると新梢が約 1 本減少する関 係にあった．さらに，着花数が増加すると葉花比が低下 することになるが，その值が10以下になると結実率も著 しく低下した.

第 1 表と第 7 図に，花器中の窒素含量と落花中の窒素 量を摘果果実及び収穫果実中のそれらと比較している. 花器中の窒素含量は平均 $3.59 \%$ で，子房よりも花弁中で 高く, がく中の含量はやや低かった。また，有葉花より も直花の方がやや高い傾向を示した．開花した花の平均

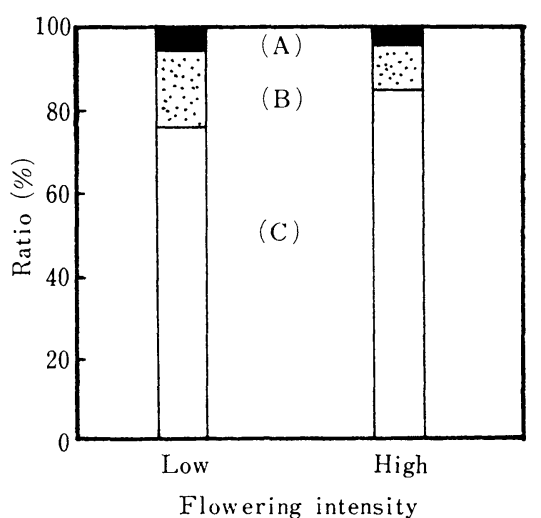

Fig. 3. The relationship between flowering intensity and types of shoot in 8-year-old Miyauchi iyo trees. Shoots were classified into 3 types; bearing shoots (A), non-bearing above $5 \mathrm{~cm}$ (B) and below $5 \mathrm{~cm}(\mathrm{C})$.

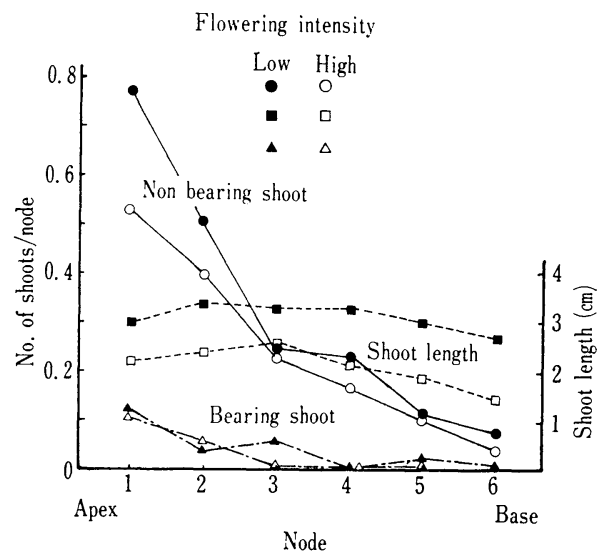

Fig. 4. Numbers of non bearing and bearing shoot per node and shoot length in relation to flowering intensity. 


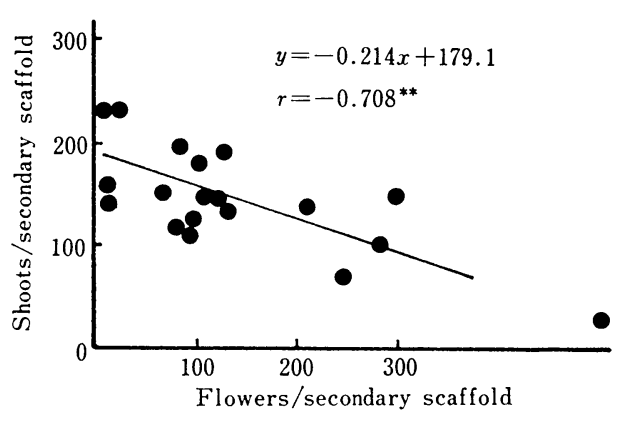

Fig. 5. The relationship between the number of flowers and the shoot growth in 8-year-old Miyauchi iyo trees.

乾物重は $67 \mathrm{mg}$ で花弁やがくの割合が高く, 子房の乾 物重は $10 \mathrm{mg}$ 以下であった. 1 花中の平均窒素含量は $2.4 \mathrm{mg}$ であった. 供試樹の平均着花数は約 1,000 個で葉

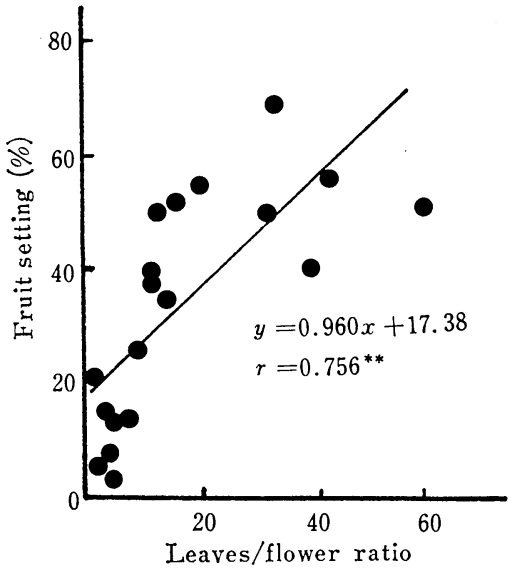

Fig. 6. The relationehip between the ratio of leaves to flowers and fruit setting in 8-year-old Miyauchi iyo trees.

Table 1. Losses of dry matter and nitrogen through the flower abscission, fruit thinning and harvest in 8-year-old Miyauchi iyo trees. Data represent the averages of 20 trees.

\begin{tabular}{|c|c|c|c|c|c|c|c|c|c|c|c|c|}
\hline \multirow{2}{*}{ Organs } & \multicolumn{2}{|c|}{ Dry matter (mg) } & \multirow{2}{*}{$\begin{array}{l}\text { No. of } \\
\text { organs/ } \\
\text { tree }\end{array}$} & \multirow{2}{*}{$\begin{array}{l}\text { No. of } \\
\text { leaves/ } \\
\text { flower } \\
\text { or fruit }\end{array}$} & \multirow{2}{*}{$\begin{array}{l}\text { No. of } \\
\text { abscised } \\
\text { organs/ } \\
\text { tree }\end{array}$} & \multicolumn{4}{|c|}{ Content of $\mathrm{N}(\%)$} & \multirow{2}{*}{$\begin{array}{l}\mathrm{N}(\mathrm{mg}) \text { in } \\
\text { abscised } \\
\text { organ }\end{array}$} & \multicolumn{2}{|c|}{$\begin{array}{l}\mathrm{N}(\mathrm{g}) \text { in abscised } \\
\text { organs }\end{array}$} \\
\hline & Ovary & Whole flower & & & & Ovary & Petal & Calyx & Organ & & /tree & $/ 10 a^{*}$ \\
\hline Flower (s) & & 67.0 & 994 & 10.3 & 858 & & & & 3.59 & 2.4 & 2.14 & 430 \\
\hline leafy & 7.1 & 16 & & & & 3.31 & 3.83 & 3.07 & & & & \\
\hline leafless & 6.8 & & & & & 3.62 & 3.80 & 3.30 & & & & \\
\hline \multicolumn{13}{|l|}{ Fruit } \\
\hline thin ned & & 7,000 & 136 & 39.0 & 67 & & & & 1.63 & 113.9 & 7.60 & 1,520 \\
\hline harvested & & 32,000 & 69 & 76.5 & 69 & & & & 0.98 & 313.6 & 1. 76 & 4,350 \\
\hline
\end{tabular}

* In the case of 200 trees planted in $10 \mathrm{a}$.
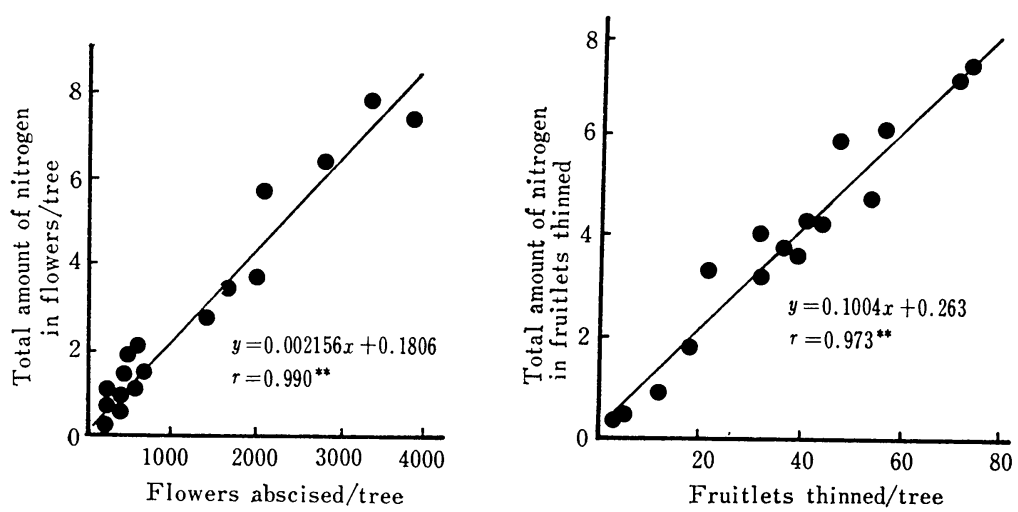

Fig. 7. Relationshipbs between the number of flowers (left) or fruitlets thinned (right) and their total amount of nitrogen per trees. Data from 20 trees of 8 -year-old Miyauchi iyo trees. 
Table 2. Effect of nitrogen application before and at anthesis on fruit setting in 5-year-old Miyauchi iyo trees.

\begin{tabular}{|c|c|c|c|c|c|c|}
\hline \multirow{2}{*}{ Treatments } & \multirow{2}{*}{$\begin{array}{l}\text { No. of } \\
\text { leaves/tree }\end{array}$} & \multirow{2}{*}{$\begin{array}{l}\text { No. of } \\
\text { flowers/tree }\end{array}$} & \multicolumn{2}{|c|}{ No. of fruit set/tree } & \multirow{2}{*}{$\begin{array}{l}\text { Fruit setting } \\
(\%)\end{array}$} & \multirow{2}{*}{$\begin{array}{l}\text { Dry weight }(\mathrm{g}) / \mathrm{fruitlet} \\
\text { a month after anthesis }\end{array}$} \\
\hline & & & Leafy & Leafless & & \\
\hline $\begin{array}{l}{ }^{15} \mathrm{~N} \text { Urea foliar spray } \\
\left({ }^{15} \mathrm{NH}_{4}\right)_{2} \mathrm{SO}_{4} \text { soil application }\end{array}$ & 400 & 189 & 22 & 21 & 22.8 & 0.41 \\
\hline March 20 & 341 & 147 & 15 & 21 & 24.5 & 0.59 \\
\hline May 8 & 329 & 163 & 9 & 7 & 9.8 & 0.38 \\
\hline Control & 418 & 174 & 9 & 8 & 9.8 & 0.16 \\
\hline
\end{tabular}

花比が約10であったが，全ての花弁と大部分の花が落 下して，それらの中に含まれる窒素量は 1 樹当たりで $2.14 \mathrm{~g}$ であった. 供試樹間の着花の多少によって，花中 の窒素含量にはほとんぞ差がなかった。したがって，落 花によって失われる窒素量は着花数に比例して增加し た. 着花数が 1,000 個の場 合には $2.16 \mathrm{~g}$ の窒素に相当 し，5,000 個着花した場合には $10.8 \mathrm{~g}$ にも達した。

供試樹の摘果前の平均葉果比は $39 て ゙ ，$ 約 $50 \%$ の果実が 摘果された．その乾物重は約 $7 \mathrm{~g}$ で, 窒素含量は平均 1.6 \%であり, 摘果果実中の窒素量は $0.11 \mathrm{~g}$ であった，摘 果果実中の窒素含量も樹間差が少なく，1樹当たりの窒 素量は摘果数に比例して增加し, その窒素量は平均 $7.6 \mathrm{~g}$ であった．花と 8 月上旬の摘果果実中の窒素量を比較す ると, 花の窒素量は後者の $1 / 40$ 以下であったが, 着花 過多樹の花数は結果過多樹の摘果数よりも40倍以上多か った．したがって，着花過多樹の落花による窒素消費量
と結果過多樹の摘果による消費量はほぼ同程度であっ

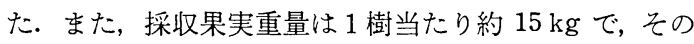
中の総窒素量は約 $22 \mathrm{~g}$ であった. 葉花比が 10 で摘果前 の葉果比が40の場合, 収穫果中の窒素に比べて落花中に 含まれる総至素量は約 $10 \%$ また，8月上旬に摘果した 果実では約35\%であった。

2. 花肥と初秋施用 ${ }^{15} \mathrm{~N}$ の花及び新梢への転 流

4 月 20 日の硫安施用と 5 月 8 日の尿素の散布によっ て，第 2 表に示すとおり，結実率が明らかに高まった。 一方，5月 8 日の硫安施用区の結実率は対照区と差がな く，また，落果が助長されて結実不足になるといら傾向 は認められなかった。

花肥施用の各区の花蕾重と子房重を第 8 困に示した. 開花前 4〜 5 日の蕾では花弁やがくの割合が大きく，子 房の割合は，有葉花及び直花のいずれも蕾重量の約 $5 \%$

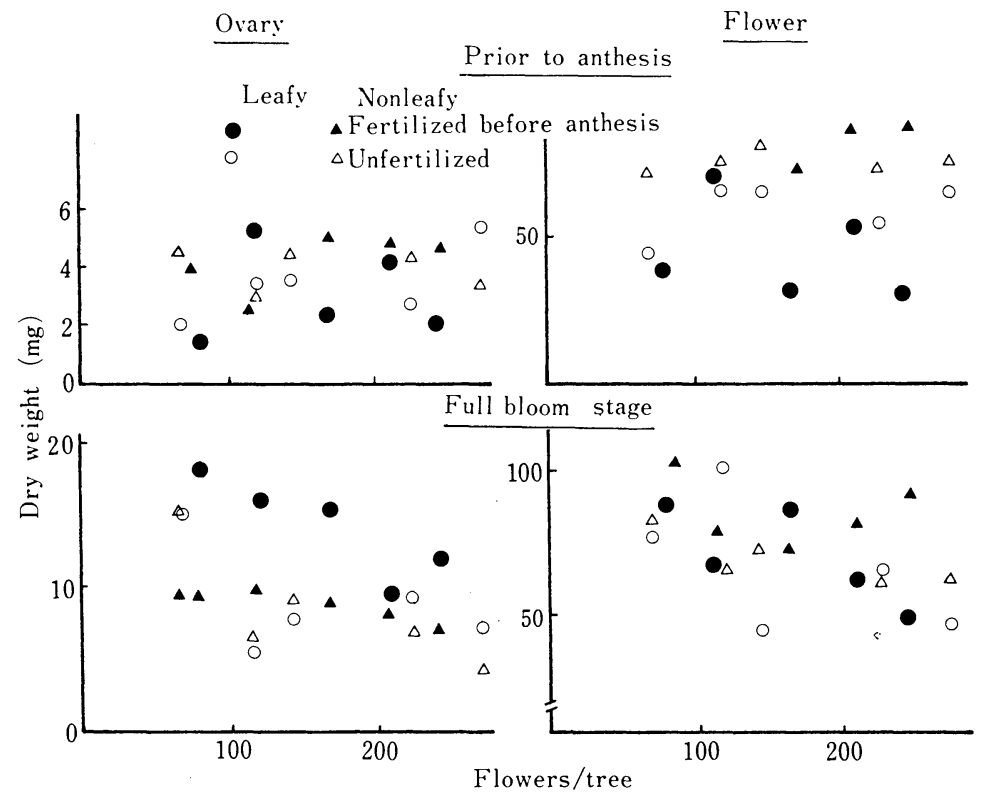

Fig. 8. Effect of nitrogen application on the weight of flower and ovary in relation to the number of flowers and the type of inflorescences. 
Table 3. Distribution of ${ }^{15} \mathrm{~N}$ applied before and at anthesis in reproductive and vegetative organs at full bloom and a month after anthesis. Content of ${ }^{15} \mathrm{~N}$ expressed as $\%$ of ${ }^{15} \mathrm{~N}$ applied.

\begin{tabular}{|c|c|c|c|c|c|c|c|c|c|c|c|c|}
\hline \multirow{3}{*}{ Treatments } & \multicolumn{6}{|c|}{ Flower organ } & \multirow{3}{*}{$\begin{array}{l}\text { Spring } \\
\text { flushes }\end{array}$} & \multirow{2}{*}{\multicolumn{2}{|c|}{ Fruitlets }} & \multirow{3}{*}{$\begin{array}{l}\text { Spring } \\
\text { flushes }\end{array}$} & \multirow{3}{*}{$\begin{array}{l}\text { Old } \\
\text { leaves }\end{array}$} & \multirow{3}{*}{$\begin{array}{l}\text { Abscised } \\
\text { flowers }\end{array}$} \\
\hline & \multirow{2}{*}{\multicolumn{2}{|c|}{$\frac{\text { Ovary }}{\text { Leafy Leafless }}$}} & \multicolumn{2}{|c|}{ Petal } & \multicolumn{2}{|c|}{ Calyx } & & & & & & \\
\hline & & & Leafy & Leafless & Leafy & Leafless & & \multicolumn{2}{|c|}{ Leafy Leafless } & & & \\
\hline Total N $(\%)$ & May 12 & & & & & & & June 15 & & & & \\
\hline \multirow{2}{*}{$\begin{aligned}{ }^{15} \mathrm{~N} \text { Urea foliar spray I } \\
\\
\text { II* }\end{aligned}$} & 2. 81 & 2. 50 & 3.30 & 3. 19 & 2. 61 & 2.05 & 3.08 & 2. 69 & 2.96 & 2. 74 & 2.18 & 3.39 \\
\hline & 2.58 & 2.55 & 3.15 & 3. 20 & 2. 41 & 2.28 & - & - & - & - & - & - \\
\hline \multicolumn{13}{|c|}{$\left({ }^{15} \mathrm{NH}_{4}\right)_{2} \mathrm{SO}_{4}$ soil application } \\
\hline March 20 & 2.41 & 2.66 & 3. 18 & 3. 15 & 2.51 & 1.95 & 3.07 & 3. 41 & 3. 18 & 3. 13 & 2. 62 & 3.00 \\
\hline May & 2.78 & 2.52 & 2.59 & 2. 72 & 2. 07 & 2. 11 & 2.57 & 3. 68 & 3. 10 & 3. 33 & 2.97 & 2.60 \\
\hline Control & 2. 72 & 2. 49 & 2. 95 & 2. 51 & 2. 24 & 2. 04 & 2.71 & 2. 44 & 2.32 & 2.59 & 2.05 & 2. 62 \\
\hline \multicolumn{13}{|l|}{${ }^{15} \mathrm{~N}$ content $(\%)$} \\
\hline \multirow{2}{*}{$\begin{array}{ll}{ }^{15} \mathrm{~N} \text { Urea foliar spray } & \mathrm{I} \\
& \mathrm{II}^{*}\end{array}$} & 13. 0 & 12.2 & 12.7 & 11.3 & 12.1 & 11.8 & 16.0 & 14.0 & 13. 4 & 16.7 & 16.3 & 18.2 \\
\hline & 10.9 & 11.6 & 9.1 & 10.0 & 9.5 & 9.5 & 6.1 & - & - & - & - & - \\
\hline \multicolumn{13}{|l|}{$\left({ }^{15} \mathrm{NH}_{4}\right)_{2} \mathrm{SO}_{4}$ soil application } \\
\hline March 20 & 11.9 & 11.8 & 15.2 & 13. 4 & 11.8 & 12.7 & 11.6 & 32.5 & 32.4 & 18. 6 & 17.9 & 20.0 \\
\hline May & 3.9 & 3.1 & 3.3 & 2.7 & 3.6 & 3.1 & 3.0 & 39.7 & 40.0 & 26.1 & 21.9 & 8.5 \\
\hline
\end{tabular}

* Flowers was covered with vinyl bags to protect from the foliar spray.

であった，蕾及び子房の重量は，有葉花よりもむしろ直 花でやや重かった．開花時の花の重量は有葉花と直花の 間でほとんど差がなかったが，この間に有葉花の子房が 急速に肥大し, 子房の重量割合は有葉花で $16.7 \%$, 直花

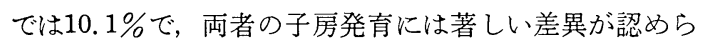
れた. 直花の重量と子房の重量に対しては, 着花数の多 少の影響がほとんど認められなかったのに，有葉花の子 房重に対しては着花の影響が認められ，着花数が増加す ると子房重がやや小さくなる傾向が認められた４月20 日の硫安区及び尿素散布区の有葉花子房重は，5月 8 日 の硫安区及び対照区に比べてかなり重かった：しかし， 直花の重量と子房重には各区にほとんど差がなかった。

花器中の窒素と ${ }^{15} \mathrm{~N}$ 寄与率を第 3 表に示した. 4 月 20 日の硫安施用区之尿素散布区の花弁やがく中の窒素含量 が高く, 5 月 8 日の硫安区の含量は対照区と差がなかっ た. 4 月 20 日硫安施用区と尿素散布区の花器中の ${ }^{15} \mathrm{~N}$ 寄 与率は，5月 8 日硫安施用区よりも顕著に高かった。 4 月20日硫安施用区の各器官の ${ }^{15} \mathrm{~N}$ 寄与率は花弁でやや 高い傾向にあったが，花と新梢及び有葉花と直花の間に 顕著な差はなかった。 また，尿素散布区では花よりも新 梢中でかなり高かったが，散布時に有葉花とその新梢を ビニル袋で覆って直接 ${ }^{15} \mathrm{~N}$ を花へ付着させなかった場 合, その枝葉の部分に比較して, 花により多くの ${ }^{15} \mathrm{~N}$ が 移行していた。満開 4 週間後の果実や新葉中の ${ }^{15} \mathrm{~N}$ 寄 与率は, 硫安施用区では満開期よりもかなり增加した が，特に 5 月 8 日硫安施用区では，4月20日施用区より も寄与率で約 $7 \%$ も高い值を示した。尿素散布区では硫
安施用区よりもかなり低く, 開花時の濃度とほとんど変 わらなかった. 落花あるいは落下した幼果中にも開花時
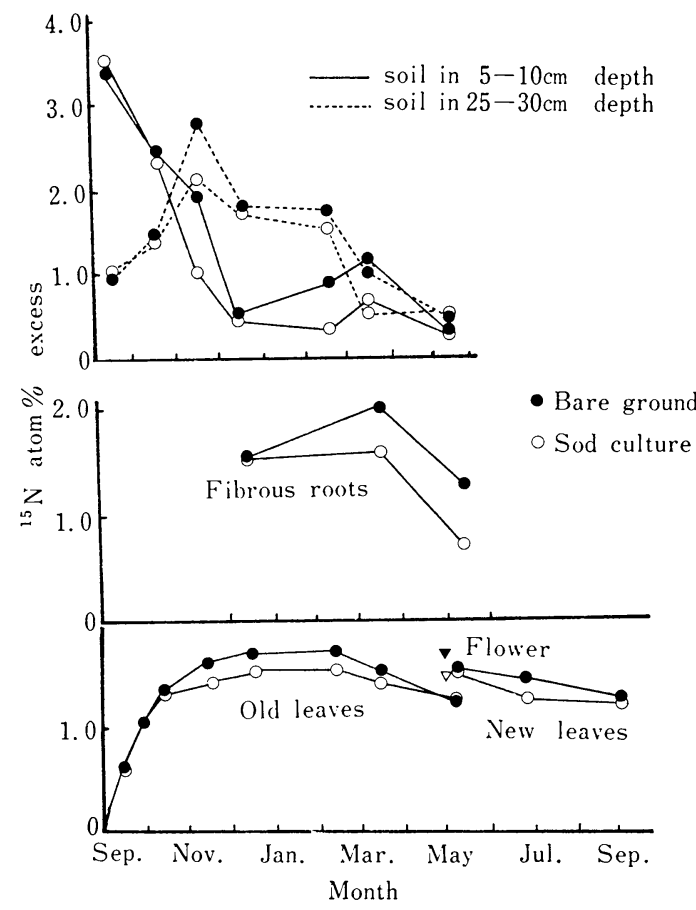

Fig. 9. Seasonal changes of the ${ }^{15} \mathrm{~N}$ content in the soil and in fibrous roots, and leaves of Miyauchi iyo trees. Nitrogen fifteen was applied as $\left({ }^{15} \mathrm{NH}_{4}\right)_{2} \mathrm{SO}_{4}$ in the soil on September 1, 1983. 
Table 4. The effect of ${ }^{15} \mathrm{~N}$ application in early Autumn on the levels ${ }^{15} \mathrm{~N}$ in the old and new organs of 8-year-old Miyauchi iyo trees in next Spring. $\left({ }^{15} \mathrm{NH}_{4}\right)_{2} \mathrm{SO}_{4}$ was applied on September 1 . Content of ${ }^{15} \mathrm{~N}$ expressed as $\%$ of ${ }^{15} \mathrm{~N}$ applied.

\begin{tabular}{|c|c|c|c|c|c|c|c|c|c|c|c|}
\hline \multirow{3}{*}{$\begin{array}{c}\text { Soil } \\
\text { managemunts }\end{array}$} & \multicolumn{6}{|c|}{ Old organs } & \multicolumn{5}{|c|}{ New organs } \\
\hline & \multirow{2}{*}{ Leaves } & \multicolumn{2}{|c|}{ Shoots } & \multirow{2}{*}{ Leaves } & \multicolumn{2}{|c|}{ Shoots } & \multicolumn{4}{|c|}{ Inflorescences } & \multirow{2}{*}{$\begin{array}{l}\text { Spring } \\
\text { flushes }\end{array}$} \\
\hline & & 1-year-old & 2-year-old & & 1-year-old & 2-year-old & Leaf y & Leafless & Ovary & Abscised & \\
\hline & March & & & May & & & & & & & \\
\hline Soil culture & 21.5 & 19.0 & 19. 4 & 18.1 & 10.7 & 11.6 & 23.2 & 22.5 & 22.5 & 21.3 & 22.9 \\
\hline Bare ground & 22.9 & 22.9 & 17.2 & 17.5 & 13.3 & 16.3 & 27.7 & 26.2 & 25.1 & 25.4 & 23. $\overline{2}$ \\
\hline
\end{tabular}

と同程度の窒素, 並びにそれ以上の ${ }^{15} \mathrm{~N}$ が含まれてい た.

一方, 前年の初秋季に施用した ${ }^{15} \mathrm{~N}$ の土壤, 細根及び 葉中の ${ }^{15} \mathrm{~N}$ 濃度の時期変化を第 9 図に示した. 9 月 1 日 に施用した ${ }^{15} \mathrm{~N}$ は，11 月中旬には 25〜30 cm の土層ま で移行したが，その層の ${ }^{15} \mathrm{~N}$ 濃度はその後徐々に低下 し， 5 月のその濃度は著しく低かった. 葉中の ${ }^{15} \mathrm{~N}$ 濃度 は施用後直ちに上昇し，11月中旬に最高に達し，2月ま ではその濃度が持続したが，その後 3 月から 5 月にかけ て低下した. 細根中の ${ }^{15} \mathrm{~N}$ 濃度も葉と同程度で, 12 月か ら 3 月にかけてやや上昇し, その後 5 月になると急激に 低下した. 3 月のせん定時と 5 月の開花期の葉や枝梢の ${ }^{15} \mathrm{~N}$ 寄与率は, 第 4 表に示した. 3 月の葉中の ${ }^{15} \mathrm{~N}$ 寄与 率は枝のそれよりも高かったが, 枝の種類については結 果母枝になる春枝で最も高かった５月の開花期の新生 器官の中では, 花中の ${ }^{15} \mathrm{~N}$ 寄与率が新梢よりもやや高か ったが, 花の種類及び落花と着生花の間の差異は小さか った. 一方, 旧葉では 3 月に比べて約 $10 〜 15 \%, 1$ 年生 枝では約 $40 \%$ 減少し, 花や新梢の寄与率に比べて20３0 \%低かった. 新葉中の ${ }^{15} \mathrm{~N}$ 濃度は 5 月以後低下した. し かし，9月になってもまだ冬期の濃度の $80 \%$ が維持され ていた.

\section{3. 開花期の ${ }^{13} \mathrm{C}$ 標識光合成産物の転流}

${ }^{13} \mathrm{CO}_{2}$ 同化処理後の各器官の ${ }^{13} \mathrm{C}$ 寄与率と移行量の変 化を第 5,6 表に示した. 蕾中の ${ }^{13} \mathrm{C}$ 寄与率は, 処理直後
には有葉花の方が直花よりも顕著に高かった. 翌朝にな ると, 有葉花及び直花の開花間近の大きい蕾の ${ }^{13} \mathrm{C}$ 寄与 率は著しく増加したが, 小さい直花の蕾はあまり増加し なかった. 処理 5 日後には, 有葉花の ${ }^{13} \mathrm{C}$ 寄与率が直花 よりも約 $50 \%$ 高く, 有葉花の花器構成部分の中では, 子 房の方が花弁やガクよりも ${ }^{13} \mathrm{C}$ 寄与率が高かった. さら に, 1 花当たりの ${ }^{13} \mathrm{C}$ 吸収量は子房の大きさによって顕 著な差が認められ, 有葉花の子房の吸収量は直花のそれ よりもかなり多く, また, 落下した花への移行量は著し く少なかった. しかし, 花の構成部分別の ${ }^{13} \mathrm{C}$ 吸収量 は, 子房よりも花弁やがくの方が多く, 花の吸収量の中 で子房の割合は有葉花で20\%，また，直花では約10\%で あった，落下した花弁や蕾の ${ }^{13} \mathrm{C}$ 寄与率は, 着生してい る有葉花の $60 \%$ 以下であったが，1樹全体での総移行量 は大きかった。

第 7 表に樹体各部位の ${ }^{13} \mathrm{C}$ の吸収量と分布割合の変化 を示した，施用炭素 (983 mg) の樹体の総吸収率は，処 理直後では85.8\%であったが，翌朝には73.8\%に，さら に 5 日後には $50 \%$ をで低下した. 花蕾による吸収は, 処 理直後には少なかったが, 翌朝には $16 \%$ に達し, さらに 5 日後になってもその量が維持されており, 花蕾は光合 成産物転流の sink として最も大きいことが認められ た. 新葉の ${ }^{13} \mathrm{C}$ 寄与率はいずれの時期も全器官中とりわ け高く, 処理直後の吸収率は43.6\%にも達した。一方, 旧葉の ${ }^{13} \mathrm{C}$ 寄与率は新葉の $1 / 5$ 以下であったが，旧葉全

Table 5. Translocation of ${ }^{13} \mathrm{C}$ metabolites in inflorescences and leaves during anthesis in 4-year-old Miyauchi iyo trees under orchard conditions. Samples were collected at $6 \mathrm{hrs}$ and $24 \mathrm{hrs}$ af ter ${ }^{13} \mathrm{CO}_{2}$ feeding.

\begin{tabular}{|c|c|c|c|c|c|c|c|c|c|c|}
\hline \multirow{2}{*}{ Organs } & \multirow{2}{*}{$\begin{array}{l}\text { of organs } \\
\text { /tree }\end{array}$} & \multicolumn{2}{|c|}{ Dry weight (mg) } & \multirow{2}{*}{$\begin{array}{c}\mathrm{C} \\
(\%)\end{array}$} & \multicolumn{2}{|c|}{${ }^{13} \mathrm{C}$ content $(\%)$} & \multicolumn{2}{|c|}{${ }^{13} \mathrm{C}(\mu \mathrm{g}) /$ organ } & \multicolumn{2}{|c|}{${ }^{13} \mathrm{C}(\mathrm{mg}) /$ tree } \\
\hline & & lorgan & /tree & & $6 \mathrm{hrs}$ & $24 \mathrm{hrs}$ & $6 \mathrm{hrs}$ & $24 \mathrm{hrs}$ & $6 \mathrm{hrs}$ & $24 \mathrm{hrs}$ \\
\hline \multicolumn{11}{|l|}{ Flower buds } \\
\hline \multirow[t]{2}{*}{ Leafy (larg } & 103 & 31.6 & 3,245 & 43.4 & 1.22 & 2. 06 & 168 & 366 & 17.3 & 40.1 \\
\hline & 317 & 11.7 & 3,717 & 41.1 & 1. 19 & 1.95 & 57 & 94 & 18.1 & 29.6 \\
\hline \multirow{2}{*}{$\begin{array}{r}\text { Leafless (large) } \\
\text { (small) }\end{array}$} & 229 & 50.5 & 11,559 & 39.1 & 0.46 & 2. 01 & 91 & 365 & 20.8 & 83.8 \\
\hline & 190 & 6.5 & 1,241 & 39.1 & 0.45 & 0.72 & 29 & 19 & 2.2 & 3.4 \\
\hline New leaves & & & 23,366 & 39.3 & 4. 67 & 4.00 & & & 428.9 & 367.1 \\
\hline Old leaves & & & 41,047 & 45.0 & 0.79 & 0.42 & & & 325.5 & 173.6 \\
\hline
\end{tabular}


Table 6. Translocation of ${ }^{13} \mathrm{C}$ metabolites in Miyauchi iyo trees 5 days af ter ${ }^{13} \mathrm{CO}_{2}$ feeding.

\begin{tabular}{|c|c|c|c|c|c|c|c|c|}
\hline \multirow{2}{*}{\multicolumn{2}{|c|}{ Organs }} & \multirow{2}{*}{$\begin{array}{l}\text { No. of organs } \\
\text { /tree }\end{array}$} & \multicolumn{2}{|c|}{ Dry weight (mg) } & \multirow{2}{*}{$\begin{array}{l}\mathrm{C} \\
(\%)\end{array}$} & \multirow{2}{*}{$\begin{array}{c}{ }^{13} \mathrm{C} \text { content } \\
(\%)\end{array}$} & \multirow{2}{*}{$\begin{array}{c}{ }^{13} \mathrm{C} / \text { organ } \\
(\mu \mathrm{g})\end{array}$} & \multirow{2}{*}{$\begin{array}{c}{ }^{13} \mathrm{C} / \text { tree } \\
(\mathrm{mg})\end{array}$} \\
\hline & & & lorgan & /tree & & & & \\
\hline \multicolumn{9}{|c|}{ Inflorescences } \\
\hline \multirow[t]{3}{*}{ Leafy } & (ovary) & 46 & 8.3 & 380 & 40.9 & 1. 66 & 56 & 2.58 \\
\hline & (petal) & 46 & 22.2 & 1,020 & 36.7 & 1.54 & 126 & 5.78 \\
\hline & (calyx) & 46 & 27.3 & 1,255 & 40.9 & 1.44 & 161 & 7. 39 \\
\hline \multirow[t]{3}{*}{ Leafless } & (ovary) & 43 & 4.0 & 173 & 40.2 & 1.05 & 17 & 0.73 \\
\hline & (petal) & 43 & 17.9 & 768 & 40.9 & 1.13 & 82 & 3.55 \\
\hline & $($ calyx) & 43 & 21.9 & 941 & 40.9 & 0.85 & 76 & 3. 28 \\
\hline \multirow[t]{3}{*}{ Abscised } & (ovary) & 33 & 2.3 & 76 & 43.5 & 0.80 & 8 & 0.27 \\
\hline & (petal) & - & - & 3,958 & 29.7 & 0.92 & & 10. 79 \\
\hline & (calyx) & - & - & 879 & 40.9 & 0.61 & & 2.18 \\
\hline \multicolumn{9}{|l|}{ Flower buds } \\
\hline \multirow[t]{2}{*}{ Leafy } & (large) & 147 & 38.1 & 5,606 & 43.4 & 1.54 & 255 & 37.42 \\
\hline & (small) & 227 & 31.8 & 7,216 & 41.1 & 1.66 & 216 & 49.08 \\
\hline \multirow[t]{2}{*}{ Leafless } & (large) & 119 & 49.2 & 5,852 & 39.1 & 1.15 & 220 & 26.21 \\
\hline & (small) & 99 & 13. 2 & 1,311 & 39.1 & 1.11 & 58 & 5.73 \\
\hline \multirow[t]{2}{*}{ Abscised } & (large) & 34 & 35.8 & 1,273 & 36.3 & 0.38 & 49 & 1. 68 \\
\hline & (small) & 91 & 16.7 & 1,523 & 36.3 & 0.63 & 38 & 3. 47 \\
\hline \multicolumn{2}{|l|}{ New leaves } & & & 23,366 & 39.3 & 2.61 & & 239.40 \\
\hline \multirow[t]{2}{*}{ Old leaves } & (spring) & & & 61,760 & 45.0 & 0.12 & & 32.22 \\
\hline & (summer) & & & 11,510 & 45.0 & 0.22 & & 11.55 \\
\hline
\end{tabular}

Table 7. Changes in the distribution pattern of ${ }^{13} \mathrm{C}$ in Miyauchi iyo trees with an advancement of time after feeding.

\begin{tabular}{|c|c|c|c|c|c|c|c|c|c|}
\hline \multirow{2}{*}{ Organs } & \multicolumn{3}{|c|}{ Amountof ${ }^{13} \mathrm{C}(\mathrm{mg})$} & \multicolumn{3}{|c|}{$\begin{array}{c}{ }^{13} \mathrm{C} \% \text { of total amount } \\
\text { of }{ }^{13} \mathrm{C} \text { applied }\end{array}$} & \multicolumn{3}{|c|}{$\%$ of ${ }^{13} \mathrm{C}$ in whole tree } \\
\hline & $6 \mathrm{hrs}$ & $24 \mathrm{hrs}$ & 5 days & $6 \mathrm{hrs}$ & $24 \mathrm{hrs}$ & 5 days & $6 \mathrm{hrs}$ & $24 \mathrm{hrs}$ & 5 days \\
\hline New leaves & 482.9 & 307.2 & 239.4 & 43.6 & 37.3 & 24.4 & 50.8 & 50.6 & 48.5 \\
\hline Old leaves & 325.5 & 173. 6 & 43.8 & 33.1 & 17.7 & 4.5 & 38.6 & 23.9 & 8.9 \\
\hline Inflorscences & 54.8 & 156.9 & 100. 1 & 5.9 & 16.0 & 16.3 & 6.5 & 21.6 & 32.8 \\
\hline Other organs & 31.2 & 27.9 & 49.8 & 3.2 & 2.8 & 5.1 & 3.7 & 3.8 & 10.1 \\
\hline Total & 844.0 & 725.5 & 493.1 & 85.8 & 73.8 & 50.3 & 100.0 & 100.0 & 100.0 \\
\hline
\end{tabular}

体による吸収量は処理直後では33.1\%で，その後急速に 低下した.なお，他の器官への移行量は著しく少なかっ た. 各時期の ${ }^{13} \mathrm{C}$ の分布割合で比較すると, 新葉への分 布割合はいずれの時期でも約 $50 \%$ でほとんど変化しなか ったが，旧葉の分布割合は急速に減少し，その減少と花 蕾の増加割合がほぼ一致していた。

\section{考察}

結実期に達した後に生育が不良になるのは, 宮内イヨ カンだけでなく，最近栽培面積が増加している早生系品 種（極早生ウンシュウなど）にも共通した性質である. これらの品種では, 良好な着花性が生産性向上に必ずし も結び付かない場合が多く(4)，むしろ，それは樹冠の 払大を不良にするなど，生産性阻害の樹体内要因とみな すことができる。
宮内イヨカンとウンシュウミカンの結果習性 $(22,24)$ を比較すると, 宮内イヨカンでは着花の程度が多いだけ でなく, 直花の不結実性に基づく弱小枝を主体とした無 着果枝の比率が顕著に高いことが特徴である. カンキツ では一般に着果負担が枝梢や細根中の貯蔵でんぷんの蓄 積を減少させる $(21,24)$ だけでなく，果実がジベレリン 様物質を生成するために $(23,26)$, それが果実着生位置 周辺枝の翌年の着花を抑制すると考えられている，宮内 イヨカンの場合には, 弱小枝に着花過多が繰り返される 傾向にあるが，弱小枝に着生するのはほとんどが直花で 結実しない.したがって，これらの枝では果実からのジ ベレリンの影響をらけることが少ないので, 毎年直花の 着花過多を繰り返すものと推測される.さらに，本種の 枝葉はわい化し，また頂芽優性が弱いために，樹冠は小 
Table 8. The effect of ${ }^{15} \mathrm{~N}$ urea foliar sprays in the middle of June on the chlorophyll, total nitrogen and ${ }^{15} \mathrm{~N}$ content in the leaves.

\begin{tabular}{|c|c|c|c|c|c|c|}
\hline \multirow{2}{*}{ Treatments } & \multicolumn{3}{|c|}{ Chlorophyll (mg/FW) } & \multirow{2}{*}{$\underset{(\%)}{\text { Total } N}$} & \multirow{2}{*}{ 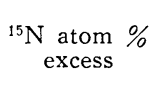 } & \multirow{2}{*}{$\begin{array}{l}\text { Content of }{ }^{15} \mathrm{~N} \\
\text { applied }(\%)\end{array}$} \\
\hline & a & $\mathrm{b}$ & $a+b$ & & & \\
\hline \multirow{2}{*}{$\begin{aligned}{ }^{15} \mathrm{~N} \text { urea } & \mathrm{I} \\
& \mathrm{II}^{*}\end{aligned}$} & 1.076 & 0.369 & 1.446 & 2.70 & 0.323 & 3.08 \\
\hline & 1.147 & 0.386 & 1.535 & 2. 70 & 0.399 & 3. 80 \\
\hline Untreated & 1.051 & 0.346 & 1. 398 & 2.72 & - & - \\
\hline
\end{tabular}

$*{ }^{15} \mathrm{~N}$ urea was sprayed with sugar ester as wetting agent. Samples were collected 5 days after spraying.

さく叢生型を示すここらの特性を植物ホルモンの面か らみると，枝葉のわい化はジベレリン不足を，また頂芽 優性が弱いことはサイトカイニンが多いことを示唆して いる $(12,16)$.

宮内イヨカンの花と新梢の間には, 花が 5 個増えると 新梢が 1 本減るといら関係が認められ, 着花数が 1 個増 加すると葉数はほぼ 1 枚の割合で減少することになる. このことは，葉果比に応じて結実させるその年の収穫果 数だけでなく，翌年の結果母枝数までが 5 月の着花量 （着花負担）の多少によって決まることを意味する. ま た, 宮内イョカン果実は 8 月中旬以後急速に肥大し, 着 果負担が增大するが，春梢や新葉は 6 月上旬にほぼ生長 を停止するので(19)，枝葉のわい化はその時すでに確定 している，すなわち，生育に対しては，秋の着果負担に 先行して着花負担が 5 月に生じていることを示唆するも のである.

Guardiola ら(5)は, 16 年生のワシントンネーブルの 着花過多樹には 100,000 個以上の花が着生し，その落花 に伴う窒素損失量は $171 \mathrm{~g}$ に達すると報告している. 宮 内イヨカンの成木でも 1 樹当たり 10,000 個以上着生する ことも多く, その場合, $10 \mathrm{a}$ 当たり 200 本植えで施肥窒 素の利用率を $50 \%$ と仮定して，落花による窒素損失量を 試算すると $8.7 \mathrm{~kg} / 10 \mathrm{a}$ の施肥窒素に相当する.この量 は, 結果過多樹の 8 月上旬の摘果中の窒素量にほぼ匹敵 し，樹体栄養的にも無視し得ない量である. しかも，そ の時期が春梢の生育期に当たるので，花による窒素の消 費が樹勢に及ぼす影響は極めて大きいと判断される.

開花期に涩められる光合成産物の転流について，門屋 （9）は旧葉がその主要な source であり，また新梢と花 蕾が $\sin \mathrm{k}$ として競合関係にあることを報告している. 本試験においても，旧葉と花蕾の間に source と sink の 関係が認められた。 また，開花初期に施用した ${ }^{13} \mathrm{C}$ 標識 光合成産物は，結実の良好な有葉花に多く移行したが， 樹全体でみた総分配量は直花の方が多いことからみて, 着花過多樹では直花が開花期における光合成産物の分配 をめぐっての競合を助長し，また落花に伴う炭素の損失 も大きいと推察される. さらに, 花の構成部分別の生長
割合を比較すると，蕾では有葉花と直花のいずれも花弁 やがくが子房よりも先に肥大し，そのために，貯蔵炭水 化物あるいはこの時期の光合成産物を先取りしている様 相が示唆された. 一方，子房は開花直前より急速に肥大 し $(3,7)$, その肥大量と開花初期の光合成産物の吸収量 によって，結実のよしあしが左右された，結実に対し て, 旧葉及び有葉花の伴葉は子房への光合成産物の供給 器官として寄与していると考えられた．花弁の結実に対 する役割は不明であるが，花弁と子房の間にも栄養上の 競合関係が存在することは明らかである。

次に，施肥窒素の転流について検討したところ，開花 3 週間前の施用 ${ }^{15} \mathrm{~N}$ は, 花と新梢及び有葉花と直花にほ ぼ均一に移行し，その分布様式には光合成産物のような 局在性は認められなかった。 また，落ちた花と着生花の 間にも ${ }^{15} \mathrm{~N}$ 濃度には差のないことから，この時期の落花 は窒素不足によるものではなく, 光合成産物の多少によ って結実が支配されているものと考えられた。すなわ ら, 開花 3 週間前の施肥及び開花初期の葉面施用窒素の 結実促進効果は, 光合成を介した間接的なものと推測さ れた。

中原 (18)や加藤 (11)は，収穫前に施用する礼肥として の窒素の動きについて報告している. 本試験の結果から も，花や新梢の形成に対する貯蔵窒素の役割が重要であ ることはよく理解される，しかし，貯蔵窒素や炭水化物 が豊富にあることが着花を一層助長することになり(8, 21,24), そうすると, それらの貯蔵養分の多くが落花に よって失われることになる．豊産性種の宮内イョカンで は，豊富な貯蔵窒素が必ずしも春梢の生育を促進するこ とにならないと推測される．開花期の新葉は，全窒素含 量が高いにもかかわらず葉色がうすい, 一方, 花肥や $5 \sim 6$ 月の葉面施用の窒素は, 新葉の緑化を促進する (第 8 表). したがって, 前年に吸収された貯蔵窒素之, 当年吸収された窒素の働きは異なっているものと考え られる. 新葉にとって，開花期は光合成産物に対して sink から source への転換期であり (9), また，窒素の利 用方式が貯蔵窒素から当年施用した窒素の利用に転換す る時期でもある.すなわち，施肥窒素が花へ多く移行す 
るかによってその転流パターンが大きく異なり, 施肥窒 素が特に着花結実（生殖生長）に貢献するか，あるいは 新葉の充実 (栄養生長) に貢献するかが決定される. 宮 内イヨカンの着花過多対策として樹勢強化のためには, 開花期ころに花肥として, 速効性肥料を窒素で $5 \sim 6 \mathrm{~kg} /$ $10 \mathrm{a}$ 程度施用するのが適切と考兄られ，この場合，落 果の助長は問題にしなくてよいと判断された.

本種栽培農家では, 肥料は一般に春肥, 夏肥, 初秋肥 及び秋肥の年 4 回に分施されている. 各時期の施肥窒素 が生育と収量に及ぼす影響を 8 年間試験した結果 (25), 春肥及び夏肥重点施用区は, 初秋肥重点施用区よりも枝 葉の生長が優れ, 収量もそれに比例して多かった. これ らのことから，ウンシュウミカンでは収穫前に施す秋肥 の効果がとかく重視されているが，宮内イヨカンではむ しろ，春肥と夏肥及びその間の花肥が重視されねばなら ないと考えられる。

\section{摘 要}

宮内イヨカンの着花過多樹における, 開花期の窒素と 光合成産物の転流を ${ }^{15} \mathrm{~N}$ と ${ }^{13} \mathrm{C}$ を用いて検討した。

（1）宮内イヨカンの着花数, 特に結実し難い直花の 增加は, 新梢の発生数を減少させ, また, 樹全体の結実 率を低下させた．落花による窒素の損失量は着花数に比 例して増加し, 葉花比が 10 以下の着花過多樹では採収果 実の $10 \%$ 以上に達した。

（2）結実率の高い有葉花では, 開花前 $4 \sim 5$ 日の間 の子房の肥大量が直花の子房よりも大きかった. 開花約 3 週間前の 4 月 20 日の施用窒素は, 満開時までに新梢や 花へ移行し, 子房の生長を促進し結実率を高めた。一 一 方, 開花初期の 5 月 8 日の施用窒素は, 結実に対する効 果は認められなかったが，開花終了後新梢へより多く移 行した. 9 月 1 日に施用した窒素の多くは11月中旬まで に吸収され，葉中の ${ }^{15} \mathrm{~N}$ 含量は翌年の 2 月まで変化し なかった， その後 3 月から 5 月の間に, 枝葉や細根中の ${ }^{15} \mathrm{~N}$ 含量は低下したのに対して, 新生器官の新葉や花中 の ${ }^{15} \mathrm{~N}$ 含量が高をった. 4 月20日及び 9 月 1 日に施用し た ${ }^{15} \mathrm{~N}$ は, 開花期の花と新梢及び着生花と落花中にほと んど均一に転流した. したがって, 花中の ${ }^{15} \mathrm{~N}$ の大部分 は落花によって損失した。

（3） ${ }^{13} \mathrm{C}$ 標識光合成產物は，結実の良好な有葉花の 子房へ多く移行したが，1樹の総移行量は落花器官中の 方が多かった：新葉中の ${ }^{13} \mathrm{C}$ 含量は全器官中で最も高 く，しかも，その割合は開花期間中变化しなかった．旧 葉中の ${ }^{13} \mathrm{C}$ 含量は急速に減少し, その減少量と花の含量 の增加量はほぼ一致した。

以上のように, 開花期の窒素と光合成産物の転流様式
にはかなりの差異が認められ，開花 3 週間前の施肥窒素 による結実促進は，光合成を介した間接的効果によると 推測されたまた，宮内イヨカンの着花過多樹の開花後 の新梢の生長促進に対しては，開花期ころの窒素の施用 が適切であると判断された。

謝 辞 本試験の ${ }^{15} \mathrm{~N}$ 及び ${ }^{13} \mathrm{C}$ の分析に際して, 御 指導を賜った農水省四国農業試験場土壤 2 科研究室の各 位に謝意を表する。

\section{引用文献}

1. 赤尾勝一郎・久保田収治・林田至人. 1978. 温州 ミカン樹の新生器官形成時における樹体内貯蔵窒 素 特に秋肥窒素の利用について. 園学雑. 47 : $31-38$.

2. 赤尾勝一郎・塚原貞雄 - 久田秀彦 - 小野祐幸. 1981. 温州ミカンの花器および新しょうの発達に およぼすほう芽期光合成産物の役、割. 園学雑. $50: 1-9$.

3. CAMERON and D. APPlEMEN. 1934. The distribution of total nitrogen in the orange tree. Proc. Amer. Soc. Hort. Sci. 30 : 341-348.

4. Goldschmidt, E. E. and S. P. MONSElise. 1977. Physiological assumption toward the development of citrus fruiting model. Proc. Int. Soc. Citriculture 2:668-672.

5. GuARdiola, J. L., F. GARCIA-MARI and M. AGUSTI. 1984. Competition and fruit set in the Washington navel orange. Physiol. Plant. $62: 297-302$.

6. 広部 誠・大垣智昭. 1969. 温州ミカンの養分吸 収に関する調查. 第 2 報. 成木樹の時期別養分吸 収について. 神奈川園試研報. $17: 18-26$.

7. 伊東秀夫. 1976. ワシントンネーブルの栽培生 理. [ I ] , [ II]. 農及園. $51: 1111-1117,1247$ -1251 .

8. 岩崎藤助・大和田厚. 1960. カンキツの隔年結果 防止に関する研究. 第 2 報. 晚秋の施肥が翌年の 着花ならびに新梢の発生に及ぼす影響. 園学雑. $29: 101-106$.

9. 門屋一臣. 1974. 温州ミカンの生長における光合 成産物の分配利用に関する研究. 愛媛大農学部紀 要. $18: 196-208$.

10. 加藤忠司. 1974. アンモニウム塩, 硝酸塩, アミ ド態窒素, アミノ酸および全窒素に含まれる重窒 素の測定について。四国農試報. $28: 151-157$.

11. 加藤忠司. 1982. ミカンを中心とした果樹の生長 と窒素の転流. 農及園. 57 : 1473-1488.

12. 近藤民雄. 1985. 樹木における 頂芽優性. 農及 園. $60: 1351-1356$.

13. 久保田収治 - 加藤忠司 - 赤尾勝一郎 - 支屋千代. 1976. 重窒素利用による, 温州ミカンの窒素の吸 収とその体内移行に関する研究. 第 4 報. 初夏肥 窒素について。四国農試報。 $29: 55-66$.

14. 久保田収治・福井春雄・本山栄一. 1974. 窒素の 
重点施用期がミカン末結実樹の生育と体内組成に 及ぼす影響. 四国農試報. $28: 105-131$.

15. 熊沢喜久雄 - 柳沢 啓. 1981. 植物試料中の ${ }^{13} \mathrm{C}$ 濃度の赤外線吸収法による定量. 土肥誌. 52 : $74-76$.

16. 增田芳雄・勝見充行・今関英雄. 1971. 植物ホル モン. p. 124-141，209-220. 朝倉書店. 東京.

17. 日園連. 1985. 果樹統計. p. 70-96. 東京.

18. 中原美智男 - 岩切 徹 - 啮谷政夫 - 小山雄生 - 西 垣 晋. 1985. アイソトープ ${ }^{15} \mathrm{~N}$ 利用によるウン シュウミカン成木樹のチッソ施肥法改善に関する 研究. 佐賀果試特別報. $3: 62-87$.

19. 新居直祐. 1978. 温州ミカン果実の初期生長に及 ぼす葉歯と摘葉処理の影響. 園学雑. $47: 172-$ 180.

20. 野間 豊・広瀬和栄. 1978. 果樹の栽培新技術委 員会編. 果樹の栽培新技術. p. 93-95. 博友社. 東京.

21. 岡田正道. 1985. ウンシュウミカンにおける樹体 養分と生産性との関係. 園学要旨. 昭60春 : 3839.

22. 大垣智昭 - 藤田克治 - 伊藤秀夫. 1963. 温州ミカ
ンの隔年結果に関する研究. 第 3 報. 温州ミカン 園の隔年結果状態, その収量構成ならびに結果と 翌年の着花率・結果枝率について. 園学雑. 32 : 13-19.

23. SAIDHA, T., E. E. GOLDSCHMIDT and S. P. MONSELISE. 1983. Endogenous growth regulations in tracheal sap of citrus. HortScience 18 : $231-232$.

24. 清水達夫 - 鳥潟博高 - 鳥居鎮男. 1975. 温州ミカ ンの着果負担に関する研究. 第 3 報. 葉果比が収 穫期の樹体内炭水化物含量ならびに翌春の着花 数・新葉数に及洔す影響. 園学雑. 43 : 423429.

25. 高木信雄 - 赤松 聡 - 大和田厚. 1984. 宮内イヨ カンの栄養条件と施肥改善に関する研究. 第 3 報. 肥料の施用時期と種類が樹勢・収量・品質に 及ぼす影響. 園学要旨. 昭59春 : 50-51.

26. 高木敏彦・鈴木鉄男・岡本 茂. 1983. ウンシュ ウミカンの着花と果実着生ならびに内生ジベレリ ン様物質の関係. 園学要旨. 昭58春 : 24-25.

27. 山浔真人・加藤忠司・塚原貞雄. 1984. 暖地ダイ ズの ${ }^{13} \mathrm{CO}_{2}$ の吸収. 土肥誌. $55: 71-72$. 